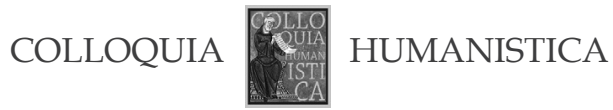

\author{
Krinka Vidaković Petrov \\ Institute of Literature and Art \\ Belgrade \\ https://orcid.org/0000-0001-6226-5563 \\ krinkavidakovic@yahoo.com
}

\title{
Transgenerational Memory: From Pre-Holocaust to Post-Yugoslavia
}

\begin{abstract}
The study focuses on Fanika as an example of documentary writing by firstand second-generation survivors, i.e. women in the mother-daughter relationship (Hanna Altarac/Fanika Lučić and Branka Jovičić), both from Sarajevo, Yugoslavia. The timeline of the life story of Hanna/Fanika, born in 1922 in a Sephardic family from Sarajevo, coincides on the macro level with the history of Yugoslavia (the establishment of the state and the interwar period, World War Two and the Holocaust, the postwar socialist period, the break-up of the country and postYugoslavia), which is important for the contextualization of the narrative. We have analyzed the motivation of first-generation survivor Fanika Lučić to present her memories of the Holocaust, highlighting the importance of communicative memory as an instrument of their transmission to a second-generation survivor as well as the process involved in their transfer from private to public narrative. Further analysis refers to the generic frames of the narrative, its hybrid character, and its liminal position at a point where biography and autobiography meet and interact. Mediation is a key procedure in Fanika, so attention has been dedicated to determining the degrees of mediation, their variation throughout the narrative and their impact on the substructures (narrative segments). Finally, we have identified,

This is an Open Access article distributed under the terms of the Creative Commons Attribution 3.0 PL License (creativecommons.org/licenses/by/3.0/pl/), which permits redistribution, commercial and non-commercial, provided that the article is properly cited. (c) The Author(s), 2020.

Publisher: Institute of Slavic Studies, Polish Academy of Sciences

Editor-in-chief: Jolanta Sujecka

Conception and academic editing of this issue: Aleksandra Twardowska, Katarzyna Taczyńska
\end{abstract}


interpreted, and contextualized several gender markers appearing at various levels of the text. In conclusion, the book was designed not only to transmit the Holocaust testimony of Fanika Lučić, but also to provide a biographical account of her life in socialist Yugoslavia, her experience of the war in Bosnia, and the final phase of her life as a Canadian immigrant. Transgenerational memory and gender play a key role in the hybrid structure of this book, which is a welcome contribution to Yugoslav Holocaust literature.

Key words: Holocaust, Yugoslavia, transgenerational memory, communicative memory, gender, biography, autobiography, hybrid genres.

\section{Transgenerational Memory in Yugoslav Holocaust Literature}

Y ugoslav women's studies did not assume its position in the academic mainstream until the post-Yugoslav period, when gender studies became an organized and publicly recognized object of scholarly attention. Within this broad field there are two specific segments: one focusing on Jewish women authors ${ }^{1}$ and the other dedicated to Yugoslav Jewish women writing about the Holocaust. ${ }^{2}$ The latter includes a smaller corpus of works distinguished by a specific feature of their inner structure. They are works in which transgenerational memory functions as a defining factor of both structure and authorship.

One example is Why They Said Nothing: Mother and Daughter on One and the Same War by Magda Bošan Simin and her daughter Nevena Simin (Novi Sad 2009). The book consists of two clearly distinct narratives, one written by Magda Bošan Simin, a first-generation survivor, and the

\footnotetext{
1 My study on "New Sephardic Literature" (in Kultura španskih Jevreja na jugoslovenskom tlu) drew Yugoslav scholars' attention to pre-Holocaust writer Laura Papo Bohoreta, whose works were later studied in more detail by Eliezer Papo, Muhamed Nezirović, Cecilia Prenz Kopušar, Jagoda Večerina Tomaić and, most recently, Magdalena Koch. Other Jewish women writers from the interwar period who have attracted the attention of scholars are Paulina Lebl Albala (Koch, in press) and Judita Šalgo (see Dražić, 2013). A recent contribution to the field is Strategies of Survival: Balkan Women and Cultural Representations of Memory (Koch \& Taczyńska, 2018). Regarding the gender issue in Sephardic folklore, see: Vidaković Petrov, 1993, 2014, 2015.

2 Israeli scholar Dina Katan Benzion was the first to draw attention to Yugoslav Jewish women writers in her study Presence and Disappearance: Jews and Judaism in Former Yugoslavia in the Mirror of Literature [Hebrew] (Katan Benzion, 2002), especially to those writing in the postHolocaust period: "The Feminine Voyage in the Post-Holocaust Jewish Literature of Former Yugoslavia" (Katan Benzion, 2014). Other studies on women's writing about the Holocaust in Yugoslavia: Badurina, 2009; Benyovsky, 1996; Taczyńska, 2017a, 2017b, 2018a, 2018b; Vidaković Petrov, 2016, 2018a.
} 
other by her daughter Nevena, a second-generation survivor. Magda's documentary text is titled Women from Bačka: Political Prisoners in the War 1941-1945. Nevena's metatext is interspersed in Magda's text, which is segmented chronologically and thematically in such a way as to allow segments of Nevena's metatext to be inserted as a sort of commentary. Text and metatext are distinct narratives subsequently combined and structured into a single narrative by Nevena after the passing of her mother in 2006 (see Vidaković Petrov, 2018a).

Another example is Fanika by Branka Jovičić (Belgrade 2017; Jovičić, 2017), a book that includes both the memories of her mother, a firstgeneration survivor from Sarajevo, and her own experiences and postmemories or meta-memories. In some ways, Fanika is analogous to the book authored by Magda and Nevena Simin, while in others it is different. Both books deal with the Holocaust in Yugoslavia, transgenerational memory as a factor of narrative structure, and a significant motherdaughter relationship. Both feature an internal dialogue between two generations represented by mother and daughter. However, unlike the first book, which refers to one war (World War Two), Fanika presents the whole life story of Hanna Altarac beginning with the prewar years in Yugoslavia and ending with the demise of the latter and a new chapter: life in exile and the forging of a new homeland. An additional difference is manifested in the type of dialogue between the first-and second-generation survivors and the different techniques used to establish the interaction between these two perspectives.

Fanika is therefore a rare example highlighting (a) the mechanisms of transgenerational memory in a single work, i.e. in the internal (narrative) rather than the external (inter-narrative) framework, (b) a Holocaust survivor's experience of not one, but two wars in the same arena (Sarajevo, Bosnia, Yugoslavia), and (c) the confrontation with the loss of the original homeland (Yugoslavia) and the construction of a new one (Canada). The life story of Hanna Altarac / Fanika Lučić is ongoing. This extraordinary lady was well into her 97th year in the summer of 2019 when I had the privilege and pleasure of meeting her, thanks to her daughter Branka Jovičić.

\section{Fanika's Life Story}

Hanna Altarac was born in 1922 as one of six children (four sons and two daughters) of Salamon Altarac and Oru (née Kabiljo) in a modest Sephardic family living in the Bjelave quarter of Sarajevo. Salamon worked in his brother's shop, Oru was a seamstress. They spoke Judeo-Spanish at 
home, kept Sephardic customs and traditions, maintained strong family ties. Hanna was very close with her younger sister Roza. Although very young, Roza fell in love with a young man (Nedžad), she got pregnant and they planned to get married in May 1941. However, on April 6 of that year Yugoslavia was invaded by Nazi Germany and its allies, and very soon the invaders carved up and occupied the country. At the same time, already on April 10, the Nazi satellite Independent State of Croatia was established. It included Bosnia, Herzegovina and part of Serbia, so Sarajevo fell under the Ustasha regime that immediately began the persecution of Serbs and Jews as well as the establishment of death camps. Hanna's father Salamon was arrested on the street and taken to a Sarajevo prison called Beledija. Soon the Ustasha arrested the eldest brother, Albert, and in July a younger brother, Isak, was taken away and executed. One day as Hanna was returning home from school, she was stopped by her cousin Bianka who told her she must not go home because her mother, sister and brothers had been taken away. Bianka told her to come with her and hide in her house. There was nothing else Hanna could do, and after a time she realized she had to assume a non-Jewish identity in order to survive. She changed her name from Hanna-Hannika to the neutral Fanika and hid first in the home of her cousin Bianka, who was safe because she was married to a Croatian. Later on her best friend Milena and her mother Smilja Kvasina convinced her to move to their home, where they hid Fanika until the end of 1944.

During the war Fanika didn't know what had happened to her family; she only received one message from her brother Izrael who was in the Jasenovac death camp. Only after the war did she find out that 63 members of her closest kin and cousins had perished: the men in Jasenovac, the women and children in the Djakovo camp.

Fanika remembered those years as times of deprivation, uncertainty and fear:

One can manage without food or water for days, I guess the body adjusts to it somehow, but it seems to me that of all human instincts, fear is the strongest one. The fear in connection with survival and self-preservation was what kept me going in the most difficult times, when I was desperate and ready to give in to the fate, thinking to surrender myself to the Ustashas. Let them take me, too. Why should I live when I don't have anyone anymore ... (Jovičić, n.d., p. 79) ${ }^{3}$

In late 1944 Fanika joined the armed resistance lead by Marshal Tito: "Joining the Partisans for me was like being liberated" (Jovičić, n.d., p. 90).

\footnotetext{
Fanika was translated into English by Mirjana Jovičić, Branislav Banjac and Michael Boonstra. However, the English version of Fanika has yet to be published, so page numbers are cited from the manuscript.
} 
Nonetheless, as many others who had lost their whole families in the war and the Holocaust, Fanika's feelings on the final liberation of Yugoslavia were ambiguous: "The whole world celebrated. I rejoiced because the terrible war, which had brought so much suffering, was over. People were reunited with their lost families, and I felt alone in the world; I sat and quietly cried. We, who had survived, remained to grieve for them; the peace came too late for us" (Jovičić, n.d., p. 92).

Peace could not liberate Fanika from feelings of tremendous loss and loneliness. Nonetheless, she too would be overtaken by the sweeping general celebration of life after all the tragedies of war: it was time for the epic reconstruction of Yugoslavia, a country left in ruins by the war. Young people would set aside past memories in order to move on into the future. Fanika had survived, she was young and healthy, so she soon got a job in a tobacco factory where she worked very hard. Then she met Lazar Lučić, a young man from Dovlići, a village on the outskirts of Sarajevo, who had spent the war years in a German labor camp. They were married in November 1946 and their first child, Branka, was born in 1948. In July 1949 their son Dragan was born, but Lazar, who had been hospitalized due to health problems, passed away in August of that year. At 27 years of age Fanika was again on her own, this time with two small children. She would never remarry, but would dedicate her life to providing warmth, love, and security to her children. She raised her children as a single mother, working hard, and she succeeded in securing a happy family life. Branka and Dragan both received a university education, got married and started families, so by the 1980s Fanika could enjoy being a grandmother - until a new war broke out in 1992.

Fanika spent this war as she had the previous one - in her hometown of Sarajevo. In 1941 she had lost her whole family. She was determined it would not happen in this war. Branka and her family managed to flee Sarajevo in May 1992, Dragan and his family did the same in 1994, so only then could Fanika consider leaving. She did so in April 1995 (eight months prior to the signing of the Dayton Accords that ended the war). Now Fanika was leaving, the only member of the family who had survived the Holocaust and the last descendant of a long line of Sephardic ancestors that had settled in Sarajevo: "Now she was the last one in the family to get out of town, after our ancestors took up settlement in Sarajevo hundreds of years before, having just fled Spain. The circle had been closed, she was leaving alone, without any family, relatives or friends" (Jovičić, n.d., p. 281). Several years ago she began writing poems. One of them concludes with lines dedicated to Sarajevo: "All my dearest ones, there remain, / Long, long ago, lost in their grave" (Jovičić, n.d., p. 293). 
Exile and the symbolic rather than geographical distance between Sarajevo and Canada had a strong impact on Fanika. She arrived in Toronto in July 1995, sponsored by the Jewish Immigrant Aid Services of Canada. Branka, Dragan, their spouses and their children were already there. The family would get together again in a new home and homeland. But even at her advanced age, Fanika keeps going back to the former Yugoslavia as if trying to bridge the "distance" that separated her from the family she had lost in the Holocaust. Memories were the main instrument of bridging the gap: they started "to creep in, surreptitiously, lurking like an invisible shadow. First in our dreams, and then they would flash through the mind when you least expect them, just to remind us of their eternal presence" (Jovičić, n.d., p. 17).

Fanika is about events that impacted the life of a first-generation Holocaust survivor as well as that of her daughter, a second-generation survivor. They are connected by a symbolic transgenerational continuity evolving in a specific place - Sarajevo, Yugoslavia. Both would end up in exile in the post-Yugoslav period. The book is also about how these events are remembered and the manner in which transgenerational memories are framed and processed in the making of an integrated narrative. Finally, the book is a meta-narrative about the telling of the story: a commentary on the act of articulating and performing narration.

\section{Survivors' Motivation for Articulating Memories in a Narrative}

The introductory chapter describes Fanika and Branka's 2010 visit to New York. The following passage narrated by Branka shows Fanika as a person unwilling to speak about her Holocaust experience:

As I glanced at Fanika, who was gazing drowsily at the glowing scenery of the city, I returned to my drifting thoughts. ... I know that she avoids talking about the difficult days in the town where she was born and where she lost so many of the people she loved, her closest family and her dear friends. Perhaps she would rather not explain it; she would usually say what she thinks in short comments, without engaging in long conversations or giving a comprehensive opinion. (Jovičić, n.d., p. 18)

In Fanika's eyes the New York cityscape must have appeared as a stark contrast to Sarajevo and the Alifakovac quarter where she had spent almost 50 years of her post-Holocaust life. Alifakovac rises steeply from 
the bank of the Miljacka River, opposite the Vijećnica, ${ }^{4}$ along narrow winding streets studded with small houses. Serbian writer Ivo Andrić described them as "buildings in their primeval namelessness and perfect modesty" that "simply serve naturally modest and happily nameless people for their few, simple needs" (Andrić, n.d.). ${ }^{5}$ Andrić spent one summer in Alifakovac, in a house very near the one in which Fanika and her family lived (Jovičić, n.d., pp. 198-199). He described the building as "a two-story house on the steep slope of Alifakovac, right near the top" and its residents as "people who care more for life itself than for what may be thought, spoken or written about it."

Fanika's house was similar - modest and simple - and Fanika herself fitted the profile of Alifakovac residents very well: anonymous ("nameless"), a working woman, a single mother, with a happy family life. Most importantly, she lived her life as best she could, speaking very little and writing nothing about it. She was apolitical and dedicated to her children, and socialized with people of her own class - cousins, friends, and neighbors, mostly women. Why would her life of mother, homemaker and caregiver be of any interest to anyone?

However, there were additional reasons for keeping silent, which she shared with many other Holocaust survivors. They refrained from talking about their experience because they wanted to bury the traumas and move on with their lives; because they wanted to avoid burdening their children; because in the aftermath of the war people had had their fill of war stories; even when there was a will to listen, the public preferred to hear about the heroic resistance of the Partisans (an officially promoted narrative) rather than about the dark world of concentration camps (especially before the Eichmann trial) or the experiences of those borrowing non-Jewish identities and surviving in hiding.

Hiding was one of several strategies of survival in Yugoslavia (Vidaković Petrov, 2017, pp. 344-346). Although some places of hiding were extreme, "in most instances they were simply a different apartment, neighborhood, town, or village in the same or a different occupation zone," while the helpers who provided shelter "were good people both young and old, from various professions, social classes, and ethnic groups" (Vidaković Petrov, 2017, pp. 359-360). In Fanika's case they were her cousin Bianka with

\footnotetext{
4 The building known as Vijećnica, built in pseudo-Moorish style, was completed in 1894 as the largest and most representative building of the Austro-Hungarian period in Sarajevo. It was originally the City Hall.

5 It is an excerpt from The House on Its Own (Kuća na osami), written 1972-1974, a year before Andrićs death in 1975, published posthumously. Andrić was awarded the Nobel Prize for Literature in 1961. He is best known for his novel The Bridge on the Drina.
} 
her Croatian husband Vid, and Fanika's best friend, the Serbian Milena Marković with her mother Smilja Kvasina. ${ }^{6}$

On a personal level, Fanika's attitude changed with the events of the 1990s which were specific for Yugoslavia: the war in Bosnia, the destruction of Yugoslavia, exile. The long journey that took Fanika from the narrow streets of Alifakovac to the wide avenues of New York made her think in a different way. She was over 70 years old and, like many other survivors, she was approaching the last part of her life. The age of the survivors prompted both them and scholars/historians to record and save the firsthand accounts of the Holocaust that would soon become unavailable. Another reason Fanika shared with other survivors was a feeling of moral responsibility: "Holocaust survivors had to confront the fact that whereas they survived, millions did not. This had a significant effect on the giving of testimony; many felt not only a moral duty to testify, but also the need to somehow account for their own survival" (Waxman, 2006, p. 88). Finally, fulfilling this responsibility implied a catharsis through the release of memories, comparable perhaps to a confession.

The turning point for Fanika happened in 2010 in New York, as described by her daughter: "I have been aware that for some time now she [Fanika] cherished a wish that some of the things she had experienced would be recorded and snatched from oblivion, but she could not do it; she didn't have the strength. She hinted a couple of times that I should do it for her" (Jovičić, n.d., pp. 18-19). From here on it was up to Branka to figure out how to fulfill her mother's wish.

\section{Communicative Memory}

Fanika transferred her memories of the Holocaust to her daughter by communicative memory throughout an extended period of time. The concept of communicative memory, introduced into memory studies by Jan Assmann, is significant for studying the transmission of Holocaust experiences by first-generation survivors:

Communicative memory is non-institutional; it is not supported by any institutions of learning, transmission, and interpretation; it is not cultivated by specialists and is not summoned or celebrated on special occasions; it is not formalized and stabilized by any forms of material symbolization; it lives in everyday interaction and communication and, for this very reason, has only a limited time depth

\footnotetext{
6 Smilja Kvasina, her daughter Milena and Vid Čop (Bianka's husband) were declared Righteous among the Nations in 2015 and Fanika came to Sarajevo to participate in the ceremony held in the Jewish Community.
} 
which normally reaches no farther back than eighty years, the time span of three interacting generations. (Assmann, 2008, p. 111)

Assmann views communicative memory as "the object of oral history, that branch of historical research that bases itself not on the usual written sources of historiography, but exclusively on memories gained in oral interviews" (Assmann, 2008, pp. 112-113). However, the organized collection of survivors' oral testimonies that began in the 1980s and continues to this day should be distinguished from communicative memory taking place in the much less structured setting of everyday communication between closest family members. We can cite three differences between the two settings. Video testimonies such as those housed at Yale, UCLA, Yad Vashem and the Spielberg collection are designed to pass from the private to the public sphere, ${ }^{7}$ while communicative memory taking place in the family may remain private and never become public. In addition, the interviewers doing the video testimonies control the communication: they steer it in line with structured and often standardized questionnaires. Finally, unlike communication in the family setting, the interviewers taping video testimonies have no affective relation to the survivor giving the testimony. Despite these differences, once communicative memory wants to pass from the private to the public sphere, it undergoes changes similar to those observed by James E. Young regarding video testimonies:

In Holocaust video testimony, therefore, at least two levels of narrative intersect: that of the film - its lateral movement, its editing - and that of the survivor's own story, its juxtaposed images - which then becomes a narrative within a narrative ... In this light the content of Holocaust video testimonies might be regarded as a combination of the survivor's story, the telling of the story, and the audiovisual taping of testimony. (Young, 1988, p. 158)

It is well known that "memory rarely comes in a long and twisting narrative skein but more often in freely associated moments, kernels of time around which events gather and accrue significance" (Young, 1988, p. 157). Such were Fanika's memories communicated to her daughter: verbally articulated fragments combined with non-verbal signs and elliptic silences, a sort of raw material that in order to be made public needed to be interpreted, organized, complemented and integrated into a meaningful

\footnotetext{
7 The organized campaign to record testimonies of survivors on video, which began in the 1980s, bypassed Fanika at that time, as it did in the 1990s when her life was at stake in Sarajevo, and when she would escape and emigrate to Canada, where she began a new life at the age of 73 . Fanika had not given her testimony to anyone except to her daughter through communicative memory. Without Fanika, the book, her testimony would have been lost altogether.
} 
narrative. This is about the telling of the story: the choice of generic frames, narrator roles, narrative structure, mediation, and interpretation.

\section{Generic Frames and Narrator Roles}

Telling the story needed to be framed, and Branka's choice was the genre of biography, which in turn implied certain conventions. However, she combines biography - telling her mother's story - with autobiography - telling the latter within the framework of her own autobiographical story. By assuming the role of biographer, in some segments Branka transmits Fanika's voice and message, so Fanika appears as the person speaking in quoted statements - narrations, descriptions, subjective states and dialogues. In these segments Fanika is identified as $I$. However, in other segments, in which Branka acts as an autobiographer, Fanika appears as a protagonist identified as she, mother, Fanika, while the narrating $I$ is identified with Branka. Although there are two perspectives, the dominant one is that of Branka - both in the role of Fanika's biographer and the narrator integrating Fanika's biography into her own autobiographical narrative.

Although telling the story involved various forms of mediation by Branka, the fact that Fanika was able to read, check and authenticate the resulting narrative provides the latter with essential credibility. The resulting narrative took Fanika's story from the private sphere to the public domain. By telling the story, putting it into writing and publishing it, Fanika would be sure that her memories of the Holocaust would not pass away with her.

\section{Segmentation of the Narrative and Degrees of Mediation}

The segmentation of the narrative features two framing chapters, one opening the narrative ("New York City 2010") and the other closing it ("Epilogue"), both referring to emigration to Canada (period of postYugoslavia). Between them are five chapters following the chronological order of events comprising the story: (1) "Sarajevo on the Eve of the Second World War" (period of the first Yugoslavia); (2) "Fanika and the Holocaust" (period of World War Two/Holocaust); (3) "Fanika's Story after the War" and (4) "Memory of Sarajevo" (period of the second Yugoslavia); and finally, "Sarajevo 1992-1995" (violent break-up of Yugoslavia).

The timeline biographically covers Fanika's personal life, which in turn coincides on the macro level with the historical "life" of Yugoslavia 
(1918-1991). Fanika stands out in Yugoslav Holocaust literature because it focuses not only on the prewar and Holocaust period (as most Holocaust testimonies do), but views the survivor also in the context of their postHolocaust life, including a direct experience of the war symbolizing the demise of Yugoslavia. It shows how the first-generation survivor coped with her Holocaust past; her family relations; interaction with the social, political and cultural environment - in this case socialist Yugoslavia; new challenges after the fall of the Berlin Wall - the war in Bosnia; and what exile meant to an aged survivor half a century after the Holocaust.

In addition to the narrative segmented in the above-mentioned chapters, there are several para-textual segments. The text is preceded by a dedication, a brief description of the narrative, and a note of gratitude. It is followed by: "Long-Time Wish Fulfilled" (how the persons who saved Fanika during the Holocaust were recognized as Righteous Among the Nations), "Family Tree" (genealogy of the Altarac and Kabiljo families, a list of those who perished in the Holocaust and a list of survivors), "In Lieu of a Prologue" (reviews by Sonja Elazar and Krinka Vidaković Petrov), and a "Bibliography" of works used by the author for supplementary information.

Theoretically speaking, the second-generation author could proceed in two ways. In most cases the emphasis is on such an author's own postmemory. However, it is also possible for the second-generation author to give precedence to the first-generation survivor's memory by recording it and assuming a mediator's role in the process of its narrative articulation. In Fanika, the interaction between the presence of mediation as well as its types and degrees show that the relationship between first- and secondgeneration survivors is a dynamic category in this context. At the beginning of the narrative, for example, Fanika's biography is given priority status, while Branka functions only as a mediator, just as an interviewer would do - by asking questions, recording her mother's responses as quotes, filling in pertinent information about the setting and timing of events (biographical data on family members, offering insights into the historical context), and providing the narrative linkage of quotes, dialogues, and descriptions. This is the model of this relationship featured in the two chapters dealing with Fanika's life prior to the war and her experiences during the Holocaust.

In the next chapter, "Fanika's Story after the War," this model changes. Here quotes of Fanika's direct speech give way to expressions such as "mother says" or "she told me," which show how Fanika gradually shifts from the status of subject (grammatical first person $I$ ) to that of object (grammatical third person she). In addition, Branka's own childhood memories begin increasingly to complement Fanika's biography in postwar 
socialist Yugoslavia. Some passages are typical for second-generation survivors describing a parent who experienced the Holocaust:

When sleep overwhelmed her, she seemed sound asleep for a period of time, but then she would start moaning, very quietly at first, but then more and more loudly. I did not understand what she was saying, but I could feel that she was having a nightmare. It seemed that she was struggling, trying to escape....

This agony she was going through seemed like an eternity to me. I could see her whole life in a second all over again, and I felt I was reliving with her the tragic experiences from the war. These nightmares, her moaning in sleep, so typical for those who went through the Holocaust, recur and last until today.

In time, life without dad settled into some kind of a routine. On weekends, we would meet with Milena, and sometimes Mom would take us to see a play in the Jewish Municipality, which she continued to frequent. (Jovičić, n.d., p. 131)

The normalization of life, the establishment of routines reinforcing stability, and the determination to cope with responsibilities towards her children, all contributed to the suppression of Fanika's trauma and her effort to keep the Holocaust experience on the margins of everyday family life. If Hanna spoke about the past with her close cousin Bianka and her best friend Milena, the two persons who had protected her while she hid in their homes during the Holocaust, they did so when the children were not there to hear them. This explains why this chapter and the next one, "Memory of Sarajevo," feature the perspective of Branka. This segment of Fanika's biography is rendered through the perspective of the secondgeneration survivor and is based on the latter's autobiographical material. In the first two chapters the degree of mediation was low, unlike these two chapters, where it is high.

In the fifth chapter, "Sarajevo 1992-1995," another change takes place. Here we see how both the first- and second-generation survivors (mother and daughter, Fanika and Branka) are confronted with a war they both experience in real time: for Fanika it was the second time, for Branka the first. During the Holocaust, Fanika was the 18-year-old Hanna Altarac, who borrowed a false identity and hid, who survived but lost her parents and siblings. In the second war Fanika Lučić was a grandmother who would reinforce her identity, refuse to hide or flee, whose main goal was to safeguard her children and grandchildren. The guilt she had harbored for being the only survivor of the Holocaust was now replaced by the courage to reinforce her identity and stay in war-torn Sarajevo.

The intersection of two perspectives is characteristic of this chapter. Branka describes her first-hand experience of the violence, bombing, 
threats, fear, insecurity and confusion that shattered normal life at the very beginning of the war in April 1992. Unlike those who thought this was a temporary break in normality, Branka sensed very early that "there would be no going back to the way things were" (Jovičić, n.d., p. 220). Branka and her family managed to flee Sarajevo by May 1992. The next four segments of this chapter describe what life was like in Sarajevo from the perspective of her mother who stayed in the city: bombings, a shortage of water and food, sniper fire, targeted killings, kidnappings, beatings, local prisons and torture/death sites, missing people, an obligation to work or layoffs, but also humanitarian assistance from the Red Cross, ADRA, and especially Jewish organizations through the Jewish Community of Sarajevo.

Most of this information was transmitted to Branka by her mother, like what happened to Fanika's two neighbors in Alifakovac. Božidar Šljivić was beaten up in his apartment and taken away, his body was eventually found "among the numerous victims at the notorious execution site otherwise known as Kazani” (Jovičić, n.d., p. 245). Goran Simić, whose father-in-law was a survivor of the Jasenovac camp (where many members of Fanika's family had perished during the Holocaust), was killed by a neighbor (Jovičić, n.d., p. 237). However, Branka refrains from describing events she herself had not witnessed, although she is aware that much of this firsthand information will probably never become public. "I was not in Sarajevo during the war, so it does not seem fair that I should speak about what others had experienced. Most people, however, never really do, but instead suppress the experienced shame and humiliation into oblivion and the farthest corners of their hearts to avoid pain, for them as well as for their children" (Jovičić, n.d., p. 245). Here is a psychological response identical to that of Holocaust survivors and other victims living with deep traumas left by their experiences of violence and war.

Branka, therefore, focuses on Fanika's own experiences in Sarajevo, which her mother communicated to her after they were reunited in Canada. This was a testimony on how a Holocaust survivor experienced the 19921995 war in Bosnia as it unfolded in Sarajevo. The degree of mediation in this segment is low.

The changes in degrees of mediation throughout the book highlight the hybrid nature of the narrative in Fanika, which consists of two types of text: mediated segments pertaining to the life story of the first-generation survivor (Fanika) and unmediated segments referring to the life story of the second-generation survivor (Branka). As we are dealing with documentary rather than fictional literature, the author (Branka Jovičić) is identified with the narrator, who constantly switches back and forth between the two roles derived from the hybrid character of the narrative. The latter 
stands in a liminal position where two genres - biography (of Hanna) and autobiography (of Branka) - meet and interact.

This is partly because the book was designed not only to transmit the Holocaust testimony of Fanika Lucić, but also to provide a biographical account of her life in socialist Yugoslavia, her experience of the war in Bosnia, and the final phase of her life as a Canadian immigrant.

\section{Gender Markers}

In their pioneering study Women in the Holocaust, Dalia Ofer and Lenore J. Weitzman indicate four structural sources of gender differences during the Holocaust. Among them, two could be relevant in the case of Fanika: "the culturally defined gender roles of Jewish men and women before the war, which endowed the two sexes with different skills, knowledge, and expertise" and "the different reactions of Jewish men and women in their everyday lives in the ghettos, the forests, and the camps as they tried to cope with the destruction they were facing" (Weitzman \& Ofer, 1998, p. 1).

Gender roles as well as their professional orientations were clearly defined in Fanika's traditional Sephardic family. The women in the family - Oru and her two daughters - were taught to adhere to these standards, which were also partially conditioned by the Altarac family's position in the social hierarchy (lower middle class). However, like many other Sephardic families in Sarajevo in the 1920s and 1930s, this family also featured a generation gap, which manifested itself in two ways. One was the higher degree of assimilation of the young generation and its stronger integration into the modern Yugoslav environment. Firstly, members of the young generation cared much less for the difference between Jews and non-Jews. Secondly, girls were on the road of emancipation and rebelled against marriage arranged by their parents, although most of them were essentially apolitical. Thirdly, they were turning their backs on tradition in order to participate in mainstream Yugoslav cultural patterns. While Roza decides to marry Nedžad, who is not a Jew, her mother does not feel comfortable with this choice. In addition, Roza is pregnant. Here is the reaction of her mother:

"Pregnant? Oh, Roza, triste di mi! [Woe is me in Judeo-Spanish]. With him, a Blahu [gentile]? Rozika, are you out of your mind? Now is not the time, the times are dangerous," she shouted fearfully. And Mom could not restrain herself: slaps and punches went flying; tears were shed along with desperate crying and sobbing. As if the skies had opened, all the sorrow and unhappiness that they had been keeping inside for days filled their humble home. It was a hard and sleepless night for everyone. (Jovičić, n.d., p. 68) 
This passage shows one more thing: that in comparison to the elder Sephardic generation, their children were less aware of the looming dangers. Another important difference: Fanika's best friend prior to the war was Milena, a Serbian girl, in whose home she would hide and survive; after the war she married Lazar Lučić, a Serb. Finally, unlike their parents, the children were completely rather than partially bilingual. This also helped Fanika survive: they spoke the "Yugoslav" (Serbo-Croatian) language like anyone else in their non-Jewish environment, without markers (accents) that would indicate their Sephardic background.

As mentioned above, the Jews in Yugoslavia would adopt one or several combined survival strategies. Two were gender-marked. One was the Partisan armed resistance, where there was a clear gender asymmetry in favor of men. The other was conversion to another religion, where the asymmetry was in favor of women: it was customary for women to convert to their husband's religion upon marriage, and this saved many Jewish women, including Fanika's cousin Bianka. Hiding does not seem to have been gender-marked, although it might have been a strategy more viable for women than for men. For example, among the Jews that attempted to pass as Aryan in the cities and countryside of Poland in 1943, "about twothirds of them [were] women" (Waxman, 2006, p. 45).

A clear gender marker in Fanika's life story was her very strong feeling of belonging to a close-knit family such as the one she was raised in. The loss of parents and siblings was by far her most painful experience and also the source of a sense of guilt (for being the only survivor) and a need to compensate for this loss/guilt. After becoming a widow at only 27 years of age, Fanika dedicated herself completely to her children and family life. Above all, she would be a generous homemaker and caregiver. When in her later life she met a man she fell in love with - he was to become a pilot - and who proposed marriage, she declined because he was willing to take in only her son, but not her daughter. She immediately refused, with indignation, renouncing her personal happiness forever in favor of her children. And she never mentioned this until her old age. Finally, her decision to stay in Sarajevo until her children and grandchildren had evacuated safely, also speaks of how Fanika compensated for not being able to save her family in the Holocaust. This, in general, is more characteristic of women as homemakers and caregivers than of men.

Men play secondary roles in Fanika's story, while Fanika's own world is interpreted as a gender-marked domain in which primary roles are played by women: Oru and Rozika (mother and sister), Bianka and Milena (cousin and friend), and finally Branka (daughter). This is also manifested in the fact that the book was the result of a close mother-daughter relationship, 
which in turn is connected with a specific aspect of communicative memory emphasized by Assmann: "Still, there are frames, 'communicative genres,' traditions of communication and thematization and, above all, the affective ties that bind together families, groups and generations" (Assmann, 2008, p. 111). The affective ties between mother and daughter are obvious. They provide the basis for transgenerational continuity and trust, also serving to generate a specific frame of communication. The latter involves a gender-marked perspective manifested in the selection of memories, their discrimination in hierarchical order, and their interpretation. Fanika's memories are focused on her family rather than her professional life; on the private rather than the public sphere; on interpersonal rather than collective or political communication; on baking everyday bread rather than coping with abstract issues.

This perspective is built into her story. In it we can easily identify the feminine world of caregivers, homemakers, family guardians. When Fanika was finally on her way out of war-torn Sarajevo, she had to go through a tunnel under the airport runway. "With two suitcases in her hands, leaning forward, in a rather humiliating posture, Fanika left Sarajevo as the last family member to do so." Knowing she was leaving for good, she would take only the things she considered the most valuable: "The suitcases contained several old, faded photographs, some embroideries and personal ID papers. Slavica's [her daughter-in-law's] handmade crafts took up a large chunk of space in the bags. Those were precious gifts she had once received from her own mother as a memento" (Jovičić, n.d., p. 281). Crochet, embroidery, knitting or sewing were traditional women's skills in Yugoslavia, and Fanika's generation was probably the last to engage in such time-consuming activities. Fanika took some of her own work because it had personal value, and even more other specimens because they were of personal value to her daughter-in-law. It was a typical gendered choice, the variations of which are found in folk songs and customs of the oral tradition. ${ }^{8}$

There is one more example. Several years after emigrating to Canada, Fanika's granddaughter was to get married, so she was looking for a wedding dress. Fanika suggested it would be great if she got married in Branka's wedding dress. The dress had been in Branka's apartment, which was later destroyed by fire. Nonetheless, Fanika insisted and explained:

\footnotetext{
In the ballads of the maiden warrior, which are prominent across Europe, the gender of the girl disguised as a soldier (because her parents had no son that could join the king's army) is to be determined by a test: which object she would wish to take - a weapon or a distaff. In Sephardic folklore in Bosnia, the custom was to encourage little boys to hold a book in their hands, while little girls were given thread or their hands were sprinkled with flour.
} 
When you left ... at the very onset of the war, when fighting broke out in your neighborhood, I have told you that back in those days I occasionally used to go to your apartment, so during one of those visits I took the dress with me and brought it to my place. Not long after that your apartment was destroyed, but I kept the dress; it was with me throughout the war. Shortly before my departure for Canada, I left the dress with Seka [a friend], so she is holding on to it now, and you can send for it whenever you like. (Jovičić, n.d., p. 300)

So, Fanika's granddaughter was married in this dress, underlining the continuity of the female ancestry line from mother to daughter to granddaughter. The dress is a gender-marked motif which also appears in the memoir of another woman Holocaust survivor from Yugoslavia: Jamila Kolonomos. Coming back home after the war, the only thing she found from her prewar life was a dress, and it was hunger in the aftermath of the war that forced Kolonomos to part with the last tangible object, a dress, symbolizing the personal tie between daughter and mother. ${ }^{9}$

Fanika's life story is quite different from the ones we usually read regarding Holocaust survivors who continued their lives in Western European countries, the United States or Israel. It is, in an essential sense, a life story that was possible only in Yugoslavia. In the 75th anniversary publication of the Jewish Immigrant Aid Services (Toronto, Canada) Fanika wrote: "My life in Sarajevo was peaceful and happy. The unique multicultural city had a special spirit and offered the opportunity of a prosperous life - until 1992, when another war broke out. Once again, my life became one of hiding, fear and famine. I lost many dear and close friends. Many fled the town. In May 1995, I too - the last one in my family - left my home and everything in it" (Jovičić, n.d., p. 304). She had lost her home, her possessions, and her country, but she saved what she cherished most - her family.

Comparing Fanika and Why They Said Nothing: Mother and Daughter on One and the Same War, mentioned at the beginning of this article, leads us to another issue we discussed in a paper presented at the congress of the EAJS in 2018: the issue of phases and models in Holocaust literature

\footnotetext{
9 Žamila (Jamila) Kolnomos, from Bitola/Monastir (Macedonia) survived by joining the Partisans. When she came home once the war was over, she found nobody from her family, her home had been sacked, she could retrieve only a few of her mother's dresses that had been given to a neighbor for safekeeping: "She returned to emptiness because there was no family or friends to celebrate liberation with. She and a handful of Bitola Jewish survivors hoped that their loved ones would also return, but as time passed, their desperation grew: no one was coming back and they were still unaware of what had happened to their family, friends and community. Once again, now in time of peace, there was hunger. And it was hunger after the war that forced Kolonomos to part with the last tangible object, a dress, symbolizing the personal tie between daughter and mother" (Vidaković Petrov, 2016, p. 255). Note: Not one of the over 7,000 Jews of Macedonia survived Treblinka.
} 
(Vidaković Petrov, 2018b). I will only present the conclusion regarding these two examples of transgenerational memory in the Yugoslav literary framework. As a result we have two types of mother-daughter (first- and second-generation Holocaust survivor) co-authorships. Both represent transitional models in the shift from the first and older type of Holocaust literature - written by first-generation survivors - to the second and later type of Holocaust literature - authored by second-generation survivors. The first model represented by Magda-Nevena moves a step away from the first type of Holocaust literature, while that represented by Fanika-Branka moves another step away, reaching the threshold of the second type of Holocaust literature. I will conclude with three observations regarding the two books under discussion.

Firstly, both books were published recently, the first in 2009 and the second in 2017. It is my conjecture that the appearance of such books involving variants of joint first-and second-generation writing is associated with the passage from the Yugoslav to the post-Yugoslav period. This is why I suggest that the two books under discussion are a new, specific postYugoslav phenomenon in Holocaust literature dealing with Yugoslav Jews; in second place, the books under discussion highlight an important change in Holocaust literature regarding the authors and the realities described in the narratives. We can observe a shift from the initial first person $I$ identified with first-generation survivors and their primary memory of the Holocaust, to the transformation of this $I$ into a third person she/he in the metamemory of second-generation survivors, and finally, to a first person I now identified with second-generation survivors writing about their own post-Holocaust experiences (but relating them to the Holocaust experienced by the previous generation). I would also like to underline the role that generational memory, a form of communicative memory, plays in this process; finally, the two books discussed above bear a clear gender marker: in both cases we have a mother-daughter relationship, suggesting a gender-marked point of view in their separate or joint narratives. This point of view is expressed in the details selected for description, the interpretation of events, the filtering of memories. These narratives convey a strong sense of the importance of family, a basic kinship unit providing terms for understanding identity not only individual, but as part of a group identity based on intergenerational continuity.

As this important issue warrants much more attention, it is discussed in detail in another article that interprets Fanika in this comparative and theoretical perspective, in which gender is viewed from a different point of view. 


\section{References}

Andrić, I. (n.d.). The house on its own / Kuća na osami. The Ivo Andrić Foundation. http:// www.ivoandric.org.rs/english/worksen/short-stories/191-the-house-on-its-own \#fragment

Assmann, J. (2008). Communicative and cultural memory. In A. Erll \& A. Nünning (Eds.), Cultural memory studies: An international and interdisciplinary handbook (pp. 109-118). https://doi.org/10.1007/978-90-481-8945-8_2

Badurina, N. (2009). Proučavanje holokausta iz ženske perspektive. In S. Prlenda (Ed.), Sjećanja žena žrtava nacizma i nedemokratskih režima (pp. 35-46). Centar za ženske studije.

Benyovsky, L. (1996). Fašistički logor Kampor na Rabu prema sačuvanim bilješkama Elvire Kohn. In I. Goldstein (Ed.), Antisemitizam, Holokaust, antifašizam (pp. 214-223). Židovska općina Zagreb.

Dražić, S. (2013). Stvarni i imaginarni svetovi Judite Šalgo. Futura.

Jovičić, B. (n.d.). Fanika (M. Jovičić, B. Banjac, \& M. Boonstra, Trans.).

Jovičić, B. (2017). Fanika. Svet knjige.

Katan Benzion, D. (2002). Nokhehut ye-he'almut: Yehudim ye-Yahadut be-Yugoslavyah le-she'avar bi-re'i ha-sifrut [Presence and disappearance, Jews and Judaism in former Yugoslavia in the mirror of literature]. Magnes Press.

Katan Benzion, D. (2014). The feminine voyage in the post-Holocaust Jewish literature of former Yugoslavia. Interkulturalnost, 2014(7), 186-191.

Koch, M. (in press). Autobiography and Biography as Tools of Cultural Manifestations of Gender in Serbian and Jewish [Counter] Memory: Paulina Lebl Albala. In M. Rajner, K. Šmid, K. Vidaković Petrov (Eds.), Crossing Borders: Jewish History and Culture in Southeastern Europe. Brill.

Koch, M., \& Taczyńska, K. (Eds.). (2018). Strategies of survival: Balkan women and cultural representations of memory [Special issue]. Studia Judaica, 2018(1[41]).

Taczyńska, K. (2017a). Pamięć matki - pamięć o matce: O Dzienniku pewnej Judyty Ženi Lebl. Miscellanea Posttotalitariana Wratislaviensia, 6, 217-231. https://doi. org/10.19195/2353-8546.6.17

Taczyńska, K. (2017b). “A scattered mosaic of records and reminiscences”: Ženi Lebl's war Odyssey in her personal writings. In U. Markowska-Manista \& J. Pilarska (Eds.), An introspective approach to women's intercultural fieldwork (pp. 68-102). Wydawnictwo Akademii Pedagogiki Specjalnej im. M. Grzegorzewskiej w Warszawie.

Taczyńska, K. (2018a). A dokąd teraz?: Problematyka obozowa w perspektywie jugosłowiańskiej: Przypadek Elviry Kohn. Acta Universitatis Lodziensis: Folia Litteraria Polonica, 47(1), 135-158. https://doi.org/10.18778/1505-9057.47.10

Taczyńska, K. (2018b). Okviri sećanja: Na primeru ličnih dokumenata Milojke Mezorane i Zlate Filipović. In M. Giger, H. Kosáková, \& M. Př́hoda (Eds.), Proměny kulturní paměti ve slovanském areálu (pp. 23-36). Filozofická fakulta Univerzity Karlovy. 
Vidaković Petrov, K. (1993). La Doncella Guerrera. Jewish Folklore and Ethnology Review, 15(2), 23-28.

Vidaković Petrov, K. (2014). The gender perspective in Sephardic ballads from the Balkans. Ladinar: Estudios en la literatura, la música y la historia de los sefardíes, 7-8, 317-328.

Vidaković Petrov, K. (2015). Tradition and gender in the Sephardic community of Macedonia. In B. Romano Nikolić (Ed.), Jews in Macedonia: History, tradition, culture, language and religion (pp. 37-48). Jewish Community in the Republic of Macedonia.

Vidaković Petrov, K. (2016). Jamila Andjela Kolonomos: de las memorias al libro conmemorativo. In P. Díaz-Mas \& E. Martín Ortega (Eds.), Mujeres sefardíes lectoras y escrituras, siglos XIX-XXI (pp. 243-260). Iberoamericana-Vervuert. https://doi.org/10.31819/9783954878864-012

Vidaković Petrov, K. (2017). The Holocaust in Yugoslavia: Questions of identity. In D. Michman (Ed.), Hiding, sheltering, and borrowing identites: Avenues of rescue during the Holocaust (pp. 343-365). The International Institute for Holocaust Research, Yad Vashem.

Vidaković Petrov, K. (2018a). Memory mediation by first- and second-generation survivors: Why they said nothing: Mother and daughter on one and the same war by Magda Bošan Simin and Nevena Simin. Studia Judaica, 2018(1[41]), 31-54. https://doi.org/10.4467/24500100STJ.18.003.9173

Vidaković Petrov, K. (2018b, July 16). Women's Holocaust literature in Yugoslavia [conference presentation]. 11th Congress of the European Association of Jewish Studies, Kraków, Poland.

Waxman, Z. V. (2006). Writing the Holocaust: Identity, testimony, representation. Oxford University Press.

Weitzman, L. J., \& Ofer, D. (1998). The role of gender in the Holocaust. In D. Ofer \& L. J. Weitzman (Eds.), Women in the Holocaust (pp. 1-18). Yale University Press.

Young, J. E. (1988). Holocaust video and cinematographic testimony. In J. E. Young, Writing and rewriting the Holocaust: Narrative and the consequences of interpretation (pp. 157-171). Indiana University Press.

\section{Трансгенерацијска меморија: од времена пре Холокауста до пост-Југославије}

Ово је студија о књизи Фаника, документарној прози аутора који припадају првој генерацији који су преживели Холокауст и другој генерацији коју чине њихова деца. То су мајка и ћерка (Хана Алтарац / Фаника Лучић и Бранка Јовичић), обе из Сарајева. Временски период обрађен у књизи обухвата животну причу Хане/Фанике, рођене 1922. у 
једној сарајевској сефардској породици, причу која се на макро-нивоу подудара с историјским трајањем Југославије (успостављање државе и међуратни период, Други светски рат и холокауст, послератно социјалистичко раздобље, разбијање земље и пост-Југословенско време), што је важно за контекстуализацију овог наратива. Анализирали смо мотивацију Фанике Лучић да представи своја сећања на холокауст, наглашавајући при томе значај комуникативне меморије као инструмента трансмисије сећања, али и као процеса њиховог преношења из приватног домена у сферу јавног дискурса. Даља анализа односи се на жанровске оквире наратива, његово хибридно одређење, као и његову граничну позицију која омогућава сусрет биографије иаутобиографијеи њиховуинтеракцију.Пошто јепосредовањепоступак од кључног значаја у Фаники, посветили смо пажњу утврђивању степеновања посредовања, његовој варијацији кроз наратив, као и његовом утицају на приповедне субструктуре (наративне сегменте). Такође смо идентификовали, тумачили и контекстуализовали неколико родних маркера који се јављају на различитим нивоима текста. Књига Фаника осмишљена је тако да омогући не само преношење сведочанства Фанике Лучић о Холокаусту, него и представљање њеног живота у социјалистичкој Југославији и њеног искуства рата у Босни, као и да пружи увид у последњу фазу Фаникиног живота - исељеништва у Канади. Трансгенерацијска меморија и род играју кључну улогу у хибридној структури ове књиге, која представља добродошли допринос југословенској литератури о Холокаусту.

Кључне речи: Холокауст, Југославија, трансгенерацијска меморија, комуникативна меморија, род, биографија, аутобиографија, хибридна структура.

\section{Pamięć międzypokoleniowa: od czasów przed Holokaustem do okresu postjugosłowiańskiego}

Artykuł analizuje książkę Fanika jako przykład prozy dokumentalnej, autorstwa dwóch kobiet należących kolejno do pierwszego i drugiego pokolenia ocalałych z Holokaustu. Są to pochodzące z Sarajewa matka i córka - Hanna Altarac/Fanika Lučic i Branka Jovičic. Ramy czasowe historii życia Hanny/Faniki (ur. 1922 w sefardyjskiej rodzinie) zbiegają się z historią Jugosławii (powstanie państwa i okres międzywojenny, II wojna światowa 
i Holokaust, powojenny socjalistyczny okres, rozpad kraju i okres postjugosłowiański), co stanowi istotny punkt wyjścia dla kontekstualizacji narracji. $\mathrm{W}$ artykule poddano analizie zarówno motywację ocalałej z pierwszego pokolenia Faniki Lučić do przedstawienia swoich wspomnień z Holokaustu, podkreślając znaczenie pamięci komunikacyjnej jako narzędzia służącego do przekazywania wspomnień ocalałemu z drugiego pokolenia, jak i proces transferu wspomnień z narracji prywatnej do publicznej. Dalsza analiza odnosi się do ogólnych ram narracji, jej hybrydowego charakteru i jej pozycji liminalnej w punkcie, w którym biografia i autobiografia spotykają się i współdziałają. Ponieważ mediacja jest procedurą kluczową w Fanice, zwrócono uwagę na określenie stopnia mediacji, jej zmienności poprzez narrację, a także jej wpływu na narracyjne podstruktury (segmenty narracyjne). Wreszcie zidentyfikowano, zinterpretowano i osadzono w kontekście kilka wyznaczników płci pojawiających się na różnych poziomach tekstu. Podsumowując, książka miała na celu nie tylko przekazanie świadectwa o Holokauście Faniki Lučić, ale także przedstawienie biograficznego opisu jej życia w socjalistycznej Jugosławii, jej doświadczeń wojny w Bośni i ostatniej fazy jej życia jako imigrantki w Kanadzie. Pamięć międzypokoleniowa i płeć odgrywają kluczową rolę w hybrydowej strukturze tej książki, która wnosi istotny wkład do jugosłowiańskiej literatury Holokaustu.

Słowa kluczowe: Holokaust, Jugosławia, pamięć międzypokoleniowa, pamięć komunikacyjna, gender, biografia, autobiografia, hybrydyczność gatunku.

Przekład z języka serbskiego

Katarzyna Taczyńska

\section{Note}

Krinka Vidaković Petrov, Institute of Literature and Art, Belgrade

krinkavidakovic@yahoo.com

The preparation of the article was self-funded by the author.

No competing interests have been declared.

\section{Publication History}

Received: 2019-11-16; Accepted: 2020-12-04; Published: 2020-12-31 